ENTREPRENEURSHIP AND SUSTAINABILITY ISSUES

ISSN 2345-0282 (online) http://jssidoi.org/jesi/

2020 Volume 7 Number 4 (June)

http://doi.org/10.9770/jesi.2020.7.4(32)

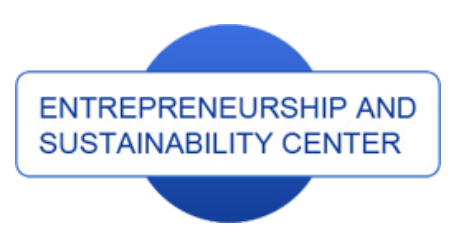

Publisher

http://jssidoi.org/esc/home

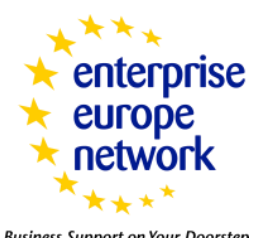

Business Support on Your Doorstep

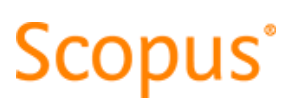

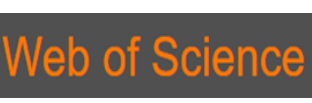

Clarivate

Analytics

\title{
A BUSINESS MODEL ANALYSIS OF BLOCKCHAIN TECHNOLOGY-BASED STARTUP*
}

\section{Joo Yeon Park ${ }^{1}$, Chang Soo Sung ${ }^{2}$}

${ }^{1}$ Discipline of Information Technology, Mathematics, Statistic, Murdoch University, 90 South Street, Murdoch, Western Australia

2. Department of Technology Entreprenerushp (Gratuate), Dongguk University, 2 Toegye-ro 36 gil, Jung-gu, Seoul, Korea

E-mails: ${ }^{1}$ jooyeon.park@murdoch.edu.au; ${ }^{2}$ redsun44@dongguk.edu

Received 22 October 2019; accepted 25 March 2020; published 30 June 2020

\begin{abstract}
Blockchain is drawing attention as rising technology with the advantages of security, transparency, and immutability by a decentralized network structure. However, blockchain technology is still an immature technology and lacks common standards. The researches on blockchain technology have been mainly focused on the financial sector but rarely applied to the supply chain in industry sectors. Especially, the blockchain technologies developed by technology entrepreneurs are still challenging to apply to an actual business due to a lack of understanding of the possibility of creating value. Therefore, it is necessary to provide technological entrepreneurs with an understanding of the business model and the feasibility of creating value with the new technology like blockchain. To address the issue, this study investigates how blockchain technology is effectively applicable and what value can be achieved from it. The purpose of this study is to analyze a livestock traceability system using blockchain technology and investigate its business model in terms of the value proposition, value delivery, and value creation. This study would provide insights into the business value creation of blockchain technology.
\end{abstract}

Keywords: Business model; blockchain technology; technology entrepreneurs; value proposition value delivery; value creation

Reference to this paper should be made as follows: Park, J.Y., Sung, Ch.S. 2020. A business model analysis of blockchain technologybased startup. Entrepreneurship and Sustainability Issues, 7(4), 3048-3060. https://doi.org/10.9770/jesi.2020.7.4(32)

JEL Classifications: M13, O32, Q16, Q55

\footnotetext{
* This business model analysis of blockchain technology is based on the Korean government project performed by a startup company, the Let's Combine.
} 


\section{ENTREPRENEURSHIP AND SUSTAINABILITY ISSUES}

ISSN 2345-0282 (online) http://jssidoi.org/jesi/

2020 Volume 7 Number 4 (June)

http://doi.org/10.9770/jesi.2020.7.4(32)

\section{Introduction}

Newly emerging IT technologies such as the Internet of Things (IoT), artificial intelligence (AI), and blockchain technology are becoming momentum to drive innovation and change in business models. Among them, blockchain technology is drawing attention as rising technology, referring to it as one of the top 10 strategic technology trends in multiple economic forums, including Davos, Gartner, and the World Economic Forum (Carson et al. 2018). Blockchain technology has the advantages of security, transparency, and immutability by providing Distributed Ledger function with a decentralized network structure. However, because blockchain is still an immature technology in its early stages and lacks common standards, blockchain technology has been rarely applied to the supply chain in industry sectors (Iansiti and Lakhani 2017). The blockchain technology seems to be concentrated in the financial industry at present, but many experts predict that it will revolutionize the present central structure system not only in the financial sector but also in the non-financial sector (Galvez et al. 2018; Tapscott and Tapscott 2017).

In particular, the blockchain technologies developed by technology entrepreneurs are challenging to apply to actual businesses due to the concerns over the possibility of creating value for companies and customers. It tends to be that many technology entrepreneurs often fail to fully understand the processes by which their technology can be applied to real business to create value and profit. Therefore, it is necessary to provide technological entrepreneurs with an understanding of the business model and the feasibility of creating value with the new technology. However, most of the blockchain research focuses on technical aspects while ignoring the managerial aspects of the application, value delivery, and value creation. Especially, there is a lack of analysis on how the blockchain technology could deliver value to the customers and suppliers of new technology companies or startups by the business model analysis. Moreover, studies focusing on application-oriented business analysis to blockchain are scarce (Risius and Spohrer 2017).

To address the issues, this study investigates how blockchain technology is effectively applicable and what value can be achieved from it. The purpose of this study is to analyze the livestock traceability system used blockchain technology from a business model perspective. This study provides an analysis of the blockchain-based traceability system along the lines of a business model in terms of the value proposition, value delivery, and value creation. This study would provide insights into the business value creation of blockchain technology.

\section{Related Studies}

\subsection{Traceability system for livestock products.}

There has been an increased risk of public health threats in livestock farms over the past two decades as severe diseases such as foot and mouth disease (FMD), and avian influenza (AI) has occurred. Therefore, many countries are building a framework for food traceability to reduce the risk of animal disease proliferation and to control imported animal products (Bai et al. 2017; Zhao et al. 2013). Many developed countries have implemented a mandatory traceability system in livestock industries for animals and their products to trace animal identification and manage breed records (Tonsor and Schroeder 2004). The Korean government announced the Act on Livestock Products on December 27, 2016 and established and operated a system called the Livestock Traceability System since then. It has replaced the previous livestock trend survey and food labeling system so that animals can be safely raised, deported, and consumed. The traceability system for livestock products ensures the safety of animal products and to strengthen the trust of consumers. The goal of the traceability system is to rigorously collect all information related to the movement of other products along the supply chain. This information is essential when faced with a food safety crisis and is vital for effective management of product recovery (Dabbene and Gay 2011). Especially, as food trade becomes globalization, the effective protection for 


\section{ENTREPRENEURSHIP AND SUSTAINABILITY ISSUES}

ISSN 2345-0282 (online) http://jssidoi.org/jesi/

2020 Volume 7 Number 4 (June)

http://doi.org/10.9770/jesi.2020.7.4(32)

fraud related to counterfeit products is important for the health and safety of global consumers (Aung and Chang 2014).

However, there still have been reported various problems for the traceability management systems in terms of data handwriting, data transparency, data consistency, and deterioration in the distribution process. Also, errors will likely occur due to the dependency of reports from implementation entities, and there is a limit to rapid backtracking if a problem is raised (Lee et al. 2017). The blockchain-based livestock traceability system has been proposed to solve these issues by collecting the history information from the object internet sensor in real-time and linking them to the blockchain (You 2018). Likewise, blockchain introduces a common technical language in the food chain, enabling product traceability through a complex supply chain from distribution to farm. The blockchain technology has been applied relatively to food chains such as food traceability systems. However, there is a lack of conventional techniques and standards for connecting different blockchains (Ciaian 2018).

\subsection{Business Model Navigator}

The concept of business model has been used in various disciplines and contexts (Zott et al. 2011; Osterwalder et al. 2005; Gassmann et al. 2014). The business model refers to a methodology that examines the possibility of creating a financial and social value of a business with the consideration of the customer's position and social environment. It undertakes to identify business failures and success factors and analyses to describe how the business of a company works (Zott et al. 2011; Osterwalder and Pigneur 2011).

Rapid changes in the environment and technology development have made significantly reduced the life cycle of companies, and companies must consider more complex social phenomena and numerous variables than in the past. In demand for changes in these business environments, the previous literature on business models has yet to establish precisely what common elements make up the business model (Gassmann et al. 2014). Moreover, many scholars recently emphasize the need to move beyond the conceptualization of business models to implementation (Al-Debei and Avison 2010; Teece 2010), because a conceptual business model is often impossible to respond quickly and actively to changes in the market.

Therefore, a business model requires to reflect the changes in the environment adequately and properly modify the relevant component. Gassmann et al. (2014) suggested a new business model called the Business Model Navigator with reducing components of business model to make it easy of use while providing a clear understanding of value proposition, delivery, and creation.

Table 1. describes the four components of the business model. The elements (What and Who) focus more on external aspects such as target customers and customer value, while the elements (Value and How) describe internal factors that distinguish a firm. In this study, we use the business model navigator to analyze the traceability systems applied with blockchain technology. Specifically, we intend to analyze the traceability system for livestock products using blockchain technology into three dimensions as the value proposition (what and who), value delivery (how) and value creation (value) based on this business model. 
ENTREPRENEURSHIP AND SUSTAINABILITY ISSUES

ISSN 2345-0282 (online) http://jssidoi.org/jesi/

2020 Volume 7 Number 4 (June)

http://doi.org/10.9770/jesi.2020.7.4(32)

Table 1. Components of the business model navigator

\begin{tabular}{|c|c|c|}
\hline Components & Question & Description \\
\hline Who & $\begin{array}{l}\text { Who are the target } \\
\text { Customers? }\end{array}$ & $\begin{array}{ll}\text { - } & \text { A clear definition of the target customers } \\
\text { - } & \text { A problem customer possesses } \\
\text { - } & \text { Classification of target customers }\end{array}$ \\
\hline What & $\begin{array}{l}\text { What value to } \\
\text { provide to the } \\
\text { customers? }\end{array}$ & $\begin{array}{ll}\text { - } & \text { A description of products or solutions } \\
\text { - } & \text { How to solve a customers' problem through the products or solutions. } \\
\text { - } & \text { Profit or value to the customers } \\
\text { - } & \text { Creativity or differences toward competitors }\end{array}$ \\
\hline How & $\begin{array}{l}\text { How to deliver the } \\
\text { value proposition? }\end{array}$ & $\begin{array}{l}\text { - A description of the various resources or capabilities associated with the business. } \\
\text { - } \quad \text { How resources or competencies align with the company's value chain. } \\
\text { - } \quad \text { Critical core partners (including suppliers) to create value. }\end{array}$ \\
\hline Value & $\begin{array}{l}\text { How to generate } \\
\text { revenue? }\end{array}$ & $\begin{array}{l}\text { - } \quad \text { The purpose of doing business. } \\
\text { - } \quad \text { The cost structure for business } \\
\text { - } \quad \text { Profit mechanism considering the cost structure for a business. } \\
\text { - } \quad \text { A comprehensive description to achieve profit generation. }\end{array}$ \\
\hline
\end{tabular}

\section{Methodology}

\subsection{Design of livestock traceability system using blockchain technology}

The livestock traceability system using blockchain technology consists of three different modes. Fig. 1 shows the first mode is the transfer system. This system extracts historical information accumulated in the public data system and transfers it to the blockchain system. The second mode is a blockchain system. This system is based on the Hyperledger Fabric algorithm, which stores and manages the livestock history data in a blockchain and processes requests from other systems. The third system is the mobile app system. It is a system that handles the request of the user in mobile and receives the request from the blockchain system and relays it. Figure 1 describes the system configuration of the traceability system for livestock products.

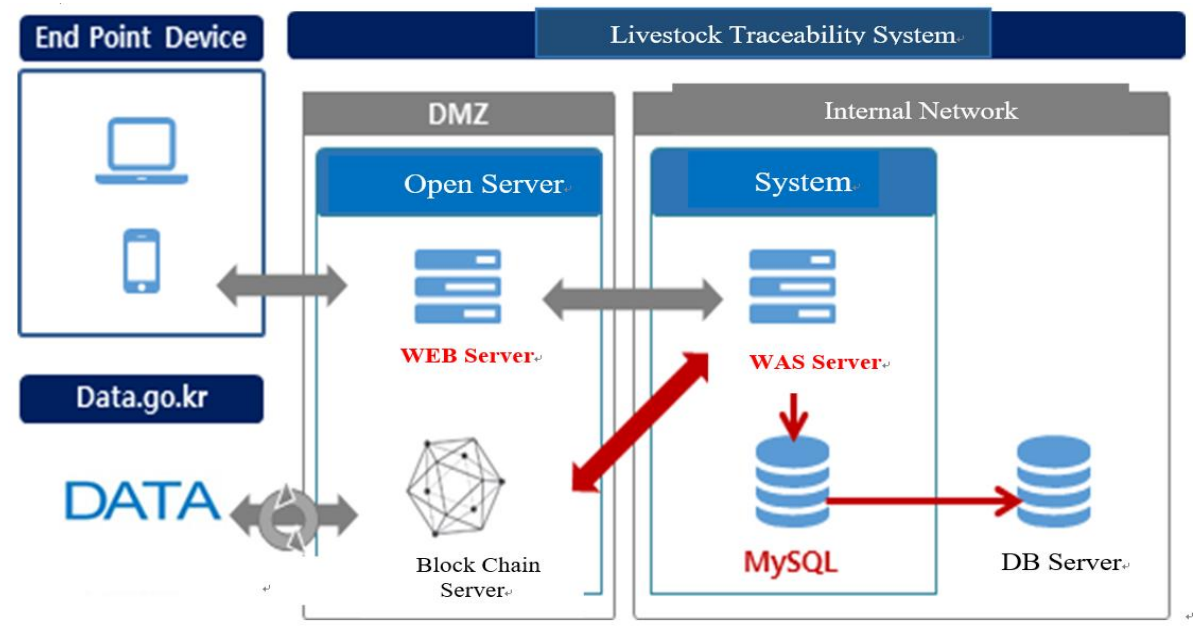

Figure 1. System configuration for Livestock Traceability System 
In using blockchain technology, a server system built on Hyperledger Fabric Algorithm developed by IBM (Table 2). Hyperledger Fabric is a block-chain software developed by the Hyperledger Project. It is an open-source project to develop a distributed framework for enterprise use. It is not a stand-alone project but a collaborative project that the Linux Foundation supports organizations, promotions, and technology infrastructures (Morris et al. 2018).

Table 2. Blockchain server configuration

\begin{tabular}{|c|c|}
\hline Division & Description \\
\hline Web Server & - Apache HTTPD \\
\hline \multirow[t]{2}{*}{ WAS } & - Tomcat 8.5 \\
\hline & - Java 8 \\
\hline DB & - MySQL \\
\hline \multirow[t]{4}{*}{ Blockchain } & - Hyperledger Fabric \\
\hline & - Docker \\
\hline & - Node.js \\
\hline & - MySQL \\
\hline $\mathrm{UI} / \mathrm{UX}$ & - Nexacro \\
\hline OS & - Ubuntu \\
\hline Mobile & - Android 4.4 above \\
\hline BLE Beacon & - BlueTooth 4.0 above \\
\hline
\end{tabular}

The data that constitutes the chain is registered in the chain as the key of the animal identification number of the livestock product, the farm identification number, and the time point when the history occurs (YYYYMMDDHHMMSS), and the generated hash value is inserted into the table as a key to respond to the encryption and decryption quickly. Figure 2 depicts data of chain configuration to be registered in the blockchain data.

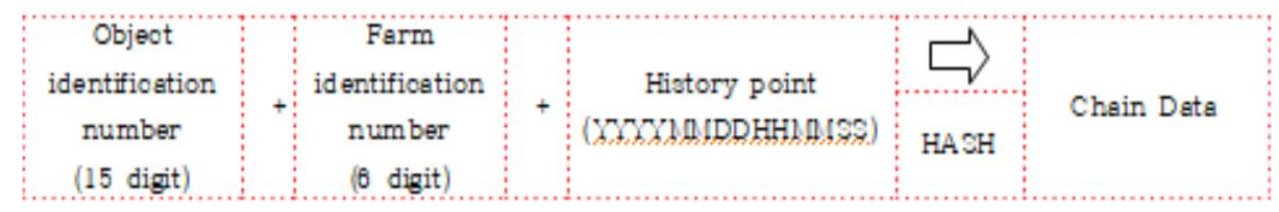

Figure 2. Chain configuration data to register in the blockchain data

The quality assessment system for livestock products is the base system to adopt the blockchain technology into the system. The livestock product quality system manages information and data about livestock products. It is public data provided by National Information Association (NIA, 2019). It should utilize the accumulated data in the process of converting the existing livestock traceability system into the blockchain-based system. Therefore, there is a need to take charge of extracting collected data and registering them in the blockchain server. In this study, the data is fetched once an hour by using the open API of livestock products registry, which is provided by the public data portal, and the registration operation is performed on the blockchain server. 
The mobile application system queries historical data stored on blockchain servers and allows users with registration rights to register changes into blockchain servers. It communicates with blockchain servers through REST APIs provided by its servers. The mobile operating system is Android in this system. The system configuration is shown in Table 3.

Table 3. Mobile App. Operation environment.

\begin{tabular}{|c|c|}
\hline Configuration & Description \\
\hline Mobile & Samsung Galaxy Note 8 \\
\hline OS & Android 8.0 above \\
\hline Development & Hybrid App \\
\hline Server communication & REST API \\
\hline
\end{tabular}

\subsection{Implementation}

It is implemented through flow as Figure 3 to display historical data of livestock products through the mobile application. Data is extracted via the Open API of the public data portal, and REST APIs created for blockchain servers are registered based on the data required by the blockchain under the rules proposed by the Open API. To communicate with blockchain servers, users must first authenticate themselves. The authentication key is issued according to the results and used to communicate with the server. Finally, mobile applications visualize and expose results to users using the REST API provided by the blockchain server.

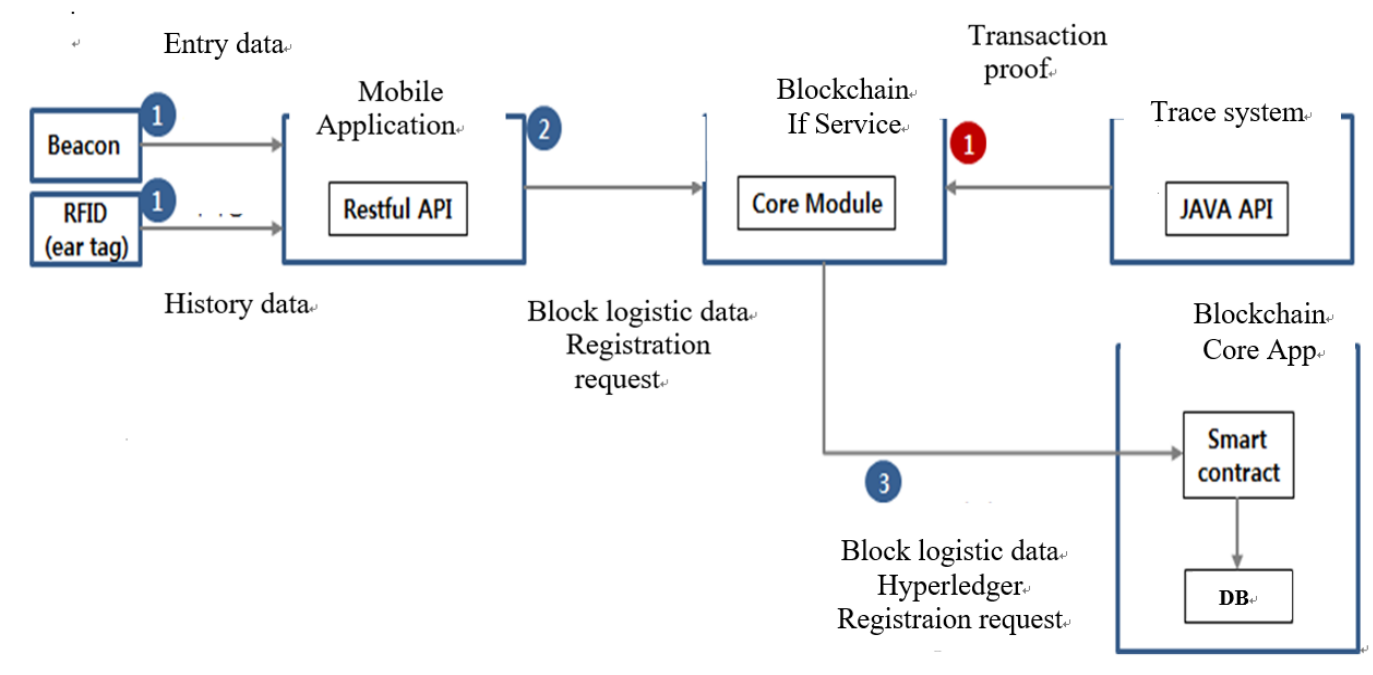

Figure 3. Implementation of Livestock Traceability System

The livestock history data provided by the public data portal is fetched once an hour and registered in the blockchain server. It is necessary to extract the corresponding data to the livestock traceability system from the public data portal through Open API. Moreover, communication with the blockchain server requires user authentication. The scope of use of search or data editing is determined according to the results of the authentication, and the corresponding authentication key is issued. This authentication key is used to 


\section{ENTREPRENEURSHIP AND SUSTAINABILITY ISSUES}

ISSN 2345-0282 (online) http://jssidoi.org/jesi/

2020 Volume 7 Number 4 (June)

http://doi.org/10.9770/jesi.2020.7.4(32)

communicate with the server. If a device has undergone the authentication process, it can receive a variety of data that is provided by blockchain servers depending on the level of authentication.

\section{Findings}

\subsection{Value proposition}

The livestock traceability system is a system necessary to prevent infection of farmers by recording and managing transactions of production, movement, and shipment of livestock farms. It enhances transparency in the distribution of livestock products by preventing them from selling, such as the false indication of origin and thus contributes to the development of livestock industry and related businesses. It is a system necessary to contribute to the healthy development of the food industry and associating business by preventing the sale of false signs. The Livestock Products Quality Assurance Agency has invested a considerable amount of money each year to maintain and improve the livestock traceability system and monitor the well-maintained system. However, the current livestock product traceability system used in this case study possesses the numbers of issues related to data transparency and deterioration in the supply-chain process. It needs to reinforce the consistency by the management agencies, and the entire system should be improved to be collectively managed and coordinated. Moreover, as shown in the supply chain for livestock products (Figure 4), the following improvements are required in the production and distribution phases:

Livestock: Dissuade large-scale, factory-style meat and introduce automatic meat.

Slaughtering process: the establishment of an organic safety management system by managing the transfer process of livestock and livestock products in the form of a chain

Distribution sales: Improvement of unsanitary distribution practices. Establishing a partial meat and refrigeration distribution system and securing data reliability according to quantification.

In responding to this issue, this case study reveals that the blockchain livestock traceability system has shown that it is not lagging in performance and function. Also, historical data accumulated in blockchain proved that it is impossible to correct under any circumstances, thus improving problems such as handwritten errors and redundancy.

The blockchain-based traceability system enhances security and is a low-cost way of managing and tracing for livestock products transactions. It also demonstrates a more transparent and, at the same time, a more secure way of tracking flows of products in livestock products supply chain than the existing DBMS based system. Notably, the blockchain-based traceability system enables distrust customers in the product information to make participating in business models. 


\begin{tabular}{|ll|}
\hline & Breeding \\
\hline$\checkmark$ & Birth notification \\
$\checkmark$ & Attaching a stamp \\
$\checkmark$ & Transfer report \\
$\checkmark$ & Death report \\
\hline
\end{tabular}

\begin{tabular}{|ll}
\hline \multicolumn{2}{|c}{ Slaughter } \\
\hline$\checkmark$ & Slaughter report \\
$\checkmark$ & Attaching Hysteresis Label \\
$\checkmark$ & Slaughtering process report \\
$\checkmark$ & DNA sampling \\
\hline
\end{tabular}
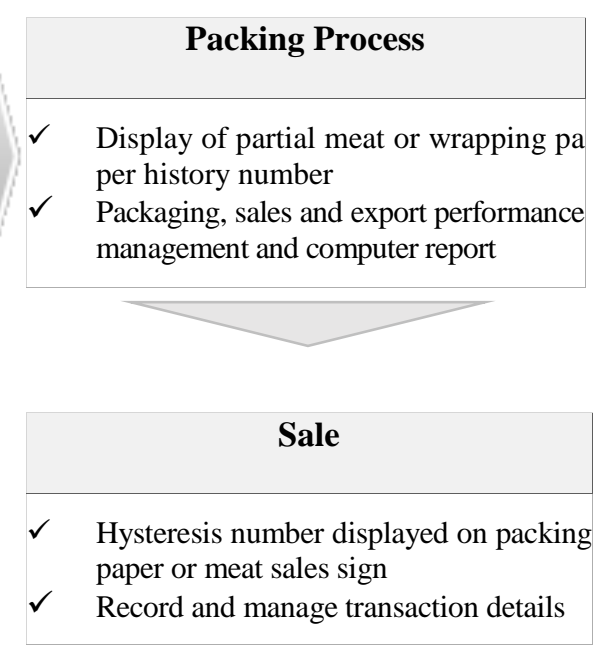

Figure 4. The supply chain for livestock products

\subsection{Value delivery}

The system structure of the traceability system for livestock products was built with a database management system (DBMS). The DBMS can edit data only by an administrator with permission to access the data. The problem of the livestock product traceability system is as Table 4.

Table 4. The problems of DBMS based traceability system

\begin{tabular}{|c|c|}
\hline Problems & Description \\
\hline Manual data management & $\begin{array}{c}\text { At the farm site, there is still a lack of a computerized system for raising livestock and reporting } \\
\text { immediately. Manual bookkeeping and vaccination certificate Data input due to handover } \\
\text { notification requires repetitive verification work and work efficiency is reduced. There is a high } \\
\text { possibility of data error due to handwriting input. }\end{array}$ \\
\hline $\begin{array}{c}\text { Ensure data transparency } \\
\text { Current Livestock Resident Registration Data is data that is processed by processing the occurrence } \\
\text { data, and it is challenging to trace original data, and data distortion due to processing is possible. It is } \\
\text { also necessary to verify data on small-sized workplaces with 5 or fewer employees. }\end{array}$ \\
\hline $\begin{array}{c}\text { Verifying data consistency } \\
\text { such as deterioration in the } \\
\text { distribution process }\end{array}$ & $\begin{array}{c}\text { Although the present Livestock Traceability System focuses on data collection, it has accomplished } \\
\text { the achievement of data infrastructure construction, but it needs analytical functions such as food } \\
\text { tracking based on the collected data. }\end{array}$ \\
$\begin{array}{c}\text { Due to the improper performance of temperature and humidity control, it is difficult to determine } \\
\text { whether the product has deteriorated during the distribution process. }\end{array}$ \\
\hline
\end{tabular}

The fundamental problem is that since the livestock product traceability system is operated based on reporting, some farmers are experiencing difficulties in their data collection due to delayed reports, neglected land management, the omission of information, and modification of data. This problem may lead to abnormalities in the number of digits due to the direct input and edit by farmers regarding their livestock breeding information. 


\section{ENTREPRENEURSHIP AND SUSTAINABILITY ISSUES}

ISSN 2345-0282 (online) http://jssidoi.org/jesi/

2020 Volume 7 Number 4 (June)

http://doi.org/10.9770/jesi.2020.7.4(32)

This chronic problem of the livestock traceability system has been confirmed through several examples using blockchain technology to collect and manage data, to secure the confidence, and to build an efficient management system. Therefore, these problems with the livestock traceability system can be solved by utilizing the various security issues of blockchain technology, and by enabling the establishment of a reliable and efficient management system. In this case study, we replaced the existing livestock traceability system using DBMS with blockchain and proved that the system based on the blockchain could improve problems with current systems such as editing errors, security, and transparency. Table 5 describes the benefits we have revealed in the blockchain-based traceability for livestock products and these are consistent with the advantages shown in the previous research (Olsen et al. 2019; Anonymous 2017).

Table 5. The characteristics of blockchain

\begin{tabular}{|c|c|}
\hline Characteristic & Description \\
\hline Suitability of database & It records transactions and is well suited for recording transformations. \\
\hline Disintermediary & $\begin{array}{r}\text { Since the notarization of the third party disappears, it is economical without a broker } \\
\text { or unnecessary commission. }\end{array}$ \\
\hline Transparency & $\begin{array}{r}\text { Since all participants share information; basically, all transactions are developed and } \\
\text { transpent level of integrity is high. }\end{array}$ \\
\hline Scalability & It is easy to build and extend by open source, which can save IT costs. \\
\hline Data quality & The frequency of fraud is low, and the risk of getting caught is high. \\
\hline Robustness & Higher trust due to the higher degree of data integrity and transparency. \\
\hline Trust &
\end{tabular}

As shown, blockchain may be appropriate to record certain kinds of information, but there may be information that is more appropriate to use existing databases. Therefore, before any organization adopts any method, it is essential to understand what needs for its database and to identify the advantages and disadvantages of each technique.

\subsection{Value creation}

Having this case study of the blockchain technology applied in the existing traceability system, we have identified several values and feasibility regarding customer satisfaction and fulfillment. The main customer of this case study is the Korea Institute for animal products quality evaluation where implements a livestock product history system. The institute aims to provide a safe environment for consumers to eat with confidence by ensuring the safety of livestock products. With this blockchain-based livestock traceability system, all related data are able to be efficiently and accurately manage, thus providing the right food environment and consumer satisfaction. From the view of a technology startup that delivers this blockchain-based livestock traceability system, not only the financial gain from the contractors but a good relationship with public institutions based on the performance of delivery or procurement of this system can be established. Moreover, further value can be expected in the future such as acquiring qualified workforce and improving technology development.

In responding to the customer value with blockching technology system, cost reduction, and the improvement of customer perception on the quality are often the major goals to deal with (Kshetri 2019). The blockchain-based livestock traceability system could provide these requirements. First, it brings customers' trust and engagement in data and systems. The food industry is becoming more customer-oriented to response fast to the needs of 


\section{ENTREPRENEURSHIP AND SUSTAINABILITY ISSUES}

ISSN 2345-0282 (online) http://jssidoi.org/jesi/

2020 Volume 7 Number 4 (June)

http://doi.org/10.9770/jesi.2020.7.4(32)

customer demand. However, having struggled with food scandals and incidents, consumers have been extremely distrustful to rely on the accumulated data on livestock products that have raised various diseases. The blockchain technology provides high-quality data from birth to death of livestock products, production method, packing data, and sales information that most customers require to see in the traceability systems. The data fraud that can cause serious disease is detected and deterred effectively through the use of blockchain, and though customers will be able to rely on the information of the traceability system (Jin and Zhou 2014). Second, blockchain makes it possible to share all information with all participants, which means all transactions on the process are transparent. This transparency of the supply chain for livestock products could result in a consistent operation and the crossmanagement. Especially it could be effective in the context of cross-border food transactions (Barnard 2017).

Thus, the blockchain deployed in the food supply chain can handle the crisis, such as food scandal more efficiently (Kshetri and Loukoianova 2019). Third, blockchain can be the key to maintain a cost-effective method and enhance the usability of the system. With a blockchain system, companies can reduce or eliminate transaction costs and easily use external resources as rich as internal resources. Also, blockchain can be effective in managing the food crisis, and it will ultimately result in lower costs for creating and providing higher value. In addition, having such benefits and efficiencies that blockchain could provide, it would be able to change the way a business organizes and manage (Tapscott and Tapscott 2017). Therefore, blockchain technology in traceability systems could result in the interest of various companies and consumers in other industry sectors as well. As showing in this case study, using blockchain will also trigger companies to develop into new business models and improve valuable services to create other beneficial services.

\section{Conclusions}

Although blockchain technology becomes the most trending technology and receives a lot of attention, the knowledge of blockchain on how it is applicable and how the value can be created has not been explored in a great deal. In responding to the research demand in question, this study identifies the blockchain-based traceability system for livestock products from the business model perspective. Having analyzed the business model with a case study, we suggest the feasibility and value creation of the livestock traceability system using blockchains. As implementing blockchain technology into an existing traceability system, it also provides an insight into the reliability of blockchain technology and possibilities of blockchain-based system in the market. We have identified that using blockchain technology to collect and manage data and establish an efficient management system can solve the chronic problems of existing animal tracking systems. In short, while blockchains are still considered as a new technology, this study suggests that the blockchain is contributing to value creation by providing practical applications where many technology entrepreneurs can gain credibility.

From this analysis, we have recognized that the blockchain technology can be applied in various fields. However, there are few actual applications in financial sectors and food sectors, and there are no best practices for leading markets so far. Moreover, there is a still lack of a study on analyzing the business feasibility for value creation and revenue generation from the eyes of a technology entrepreneur. Ultimate business value can be reached with interactive consequences of other constitutive factors. However, as presented in this study, the individual characteristics of blockchain applied for each application domain will facilitate mechanisms for adjusting blockchain to suit the application's actual needs and utilization of appropriate blockchain (Casino et al. 2019). Companies interested in designing blockchains, they should set the goal and ask themselves questions such as what value to capture with it, who to serve the value and how to deliver it (Felin and Lakhani 2018). Companies can use various methodologies to analysis such questions in a strategic way, and, especially startup companies with expertise in high technology should carefully consider value creation for associated stakeholders with examining business model analysis. 


\section{ENTREPRENEURSHIP AND SUSTAINABILITY ISSUES}

ISSN 2345-0282 (online) http://jssidoi.org/jesi/

2020 Volume 7 Number 4 (June)

http://doi.org/10.9770/jesi.2020.7.4(32)

This study is meant to encourage new technology entrepreneurs to provide business feasibility of technology as applying new blockchain technology into the traceability system. However, this study has limitations to be considered in future research. The blockchain technology has great potential to be extended in various industrial sectors, but it is hard to generalize the outcome of its advantages since the common standards and language is the lack at this point. Moreover, the business model analysis should be considered not only for the technology benefit itself but to view various complicated factors in a digitally networked environment. This study brings in simplifying to showing the advantages of blockchain technology. In future research, the business factors in different industries also need to be counted to generalize the feasibility of the new technology into the business model.

\section{References}

Al-Debei, M. M. \& Avison, D. 2010. Developing a unified framework of the business model concept. European Journal of Information Systems, 19: 359-376.

Anonymous 2017. Blockchain Technology: Will it make a difference? The Electricity Journal, 30: 85-88. Retrieved from http://dx.doi.org/10.1016/j.tej.2017.04.007

Aung, M.M. \& Chang, Y. S. 2014. Traceability in a food supply chain: Safety and quality perspectives. Food Control, 39: 172-184.

Bai, H., Zhou, G., Hu, Y., Sun, A., Xu, X., Liu, X. \& Lu, C. 2017. Traceability technologies for farm animals and their products in China. Food control, 79: 35-43.

Barnard, B. 2017. Maersk, IBM Digitalize Global Container Supply Chain (12 April). JOC.ccom Retrieved from: https://www.joc.com/maritime-news/container-lines/maersk-line/maersk-ibm-digitalize-global-container-supply-chain_20170306.html

Carson, B. Romanelli, G. Walsh, P. and Zhumaev, A. 2018. Blockchain beyond the hype: What is the strategic business value? McKinsey Digital, McKinsey \& Company, retrieved from https://www.mckinsey.com/business-functions/digital-mckinsey/our-insights/blockchainbeyond-the-hype-what-is-the-strategic-business-value

Casino, F., Dasaklis, T. \& Patsakis, C. 2019. A systematic literature review of blockchain-based applications: Current status, classification and open issues. Telematics and Informatics, 36: 55-81.

Ciaian, P. 2018. Blockchain technology and market transparency. Retrieved from https://ec.europa.eu/info/sites/info/files/law/consultation/mt-workshop-blockchain-technology-and-mt_ciaian_en.pdf

Dabbene, F. \& Gay, P. 2011. Food traceability systems: Performance evaluation and optimization. Computers and Electronics in Agriculture, 75: 139-146.

Felin T. \& Lakhani, K. 2018. What problems will you solve with blockchain? MIT Sloan Management Review, Fall 32-38.

Galvez, J.F., Mejuto, J.C. \& Simal-Gandara, J. 2018. Future challenges on the use of blockchain for food traceability analysis. Trends in Analytical Chemistry, 107: 222-232.

Gassmann, O., Frankenberger, K. \& Csik, M. 2014. The Business Model Navigator: 55 Models That Will Revolutionise Your Business, FT Publishing, UK: Pearson Education Limited.

Iansiti, M. \& Lakhani, K.R. 2017. The truth about blockchain. Harvard Business Review, 95(1): 118-127.

Jin, S. \& Zhou, L. 2014. Consumer interest in information provided by food traceability systems in Japan. Food Quality and Preference, 36: $144-152$.

Kshetri, N. \& Loukoianova, E. 2019. Blockchain adoption in supply chain networks in Asia. IEEE IT Professional, 21(1): 11-15.

Kshetri, N. 2019. Blockchain and the economics of customer satisfaction. IT Professional, Jan./Feb. 93-97. 


\section{ENTREPRENEURSHIP AND SUSTAINABILITY ISSUES}

ISSN 2345-0282 (online) http://jssidoi.org/jesi/

2020 Volume 7 Number 4 (June)

http://doi.org/10.9770/jesi.2020.7.4(32)

Lee, H., Kim, J. Seo, H. \& Kim, C. 2017. Hysteretic Substitution and Implications of Cattle Farm Statistics. Korea Rural Economic Research Institute, 149: 1-16.

Morris, V. Adivi, R., Asara, R. Consens, M., Gupta, N, Lincoln, N. Mosakowski, B. \& Sun H. 2018. Developing a Blockchain Business Network with Hyperledger Composer using the IBM Blockchain Platform Starter Plan, Red paper, IBM Corp.

National Information Association (NIA). 2019. Livestock quality information, Public data portal, retrieved from https://www.data.go.kr/dataset/15000483/openapi.do

Olsen, P., Borit, M. \& Syed, S. 2019. Applications, limitations, costs, and benefits related to the use of blockchain technology in the food industry, Nofima report, April. Norway. Retrieved from www.nofima.no.

Osterwalder, A., Pigneur, Y. \& Tucci, C. 2005. Clarifying business models: Origins, present, and future of the concept. Communications of AIS, 15: 2-40.

Osterwalder, A. \& Pigneur, Y. 2011. Business Model Generation: A Handbook for Visionaries, Game Changers, and Challengers. Hoboken, NU: John Wiley \& Sons, Inc.

Risius, M. \& Spohrer, K. 2017. A Blockchain Research Framework: What we (don't) know, Where we go from here, and How we will get there. Business \& Information System Engineering, 59(6): 385-409. https://doi.org/10.1007/s12599-017-0506-0

Solaimani, S., Heikkila, M. \& Bouwman, H. 2018. Business Model Implementation within Networked Enterprises: A Case Study on a Finnish Pharmaceutical Project. European Management Review, 15: 79-96.

Tapscott, D. \& Tapscott, A. 2017. How blockchain will change organizations. MIT Sloan Management Review, 58(2): 9-13.

Teece, D. J. 2010. Business models, business, strategy and innovation. Long Range Planning, 43: 172-194.

Tonsor, G. T., \& Schroeder, T. C. 2004. Australia's livestock identification systems: Implications for United States programs. United States Department of Agriculture.

You, U. 2018. Complementing the livestock product history system with blockchain technology, retrieved from, Korea farm newspaper, http://www.newsfarm.co.kr/news/articleView.html?idxno=30623

Zhao, Y., Zhang, B., Chen, G., Chen, A., Yang, S., \& Ye, Z. 2013. Tracing the geographic origin of beef in China on the basis of the combination of stable isotopes and multielement analysis. Journal of Agricultural and Food Chemistry, 61(29): 7055-7060.

Zott, C., Amit, R. \& Massa, L. 2011. The business model: Recent developments and future research, Journal of Management, 37: 10191042 .

\section{Acknowledgments}

This business model analysis of blockchain technology is based on the Korean government project performed by a startup company, the Let's Combine. The authors thank Chi-Ha Kim, the CEO of the Let's Combine co. for making it possible to use data and carry on this research. 


\section{ENTREPRENEURSHIP AND SUSTAINABILITY ISSUES}

ISSN 2345-0282 (online) http://jssidoi.org/jesi/

2020 Volume 7 Number 4 (June)

http://doi.org/10.9770/jesi.2020.7.4(32)

Joo Yeon PARK is a lecturer in Information Technology at the College of Science, Health, Engineering and Education, Murdoch University Western Australia. Her research interest spans various subjects including digital entrepreneurship, innovation, management information systems, IT education, security and privacy. Her research has been published in a number of peer-reviewed journals such as Information \& Management, Knowledge Management Research \& Practice.

ORCID ID: https://orcid.org/0000-0002-5231-5405

Chang Soo SUNG is an assistant professor in the Dept. of Technology Entrepreneurship in Graduate School at Dongguk University, South Korea. He is a director of Entrepreneurship Research Center in Dongguk University and has been actively working for the curriculum development for entrepreneurship education. He is a chairman of the Planning Committee \& Audit in Korea Association of Entrepreneurship Education in Korea and an editor of the Journal of Korean Entrepreneurship Society. His current research interests include Smart device, IoT, Technology Entrepreneurship and interdisciplinary research.

ORCID ID: https://orcid.org/0000-0002-6205-638X

Register for an ORCID ID:

https://orcid.org/register

Copyright (C) 2020 by author(s) and VsI Entrepreneurship and Sustainability Center

This work is licensed under the Creative Commons Attribution International License (CC BY).

http://creativecommons.org/licenses/by/4.0/

c) (i) Open Access 